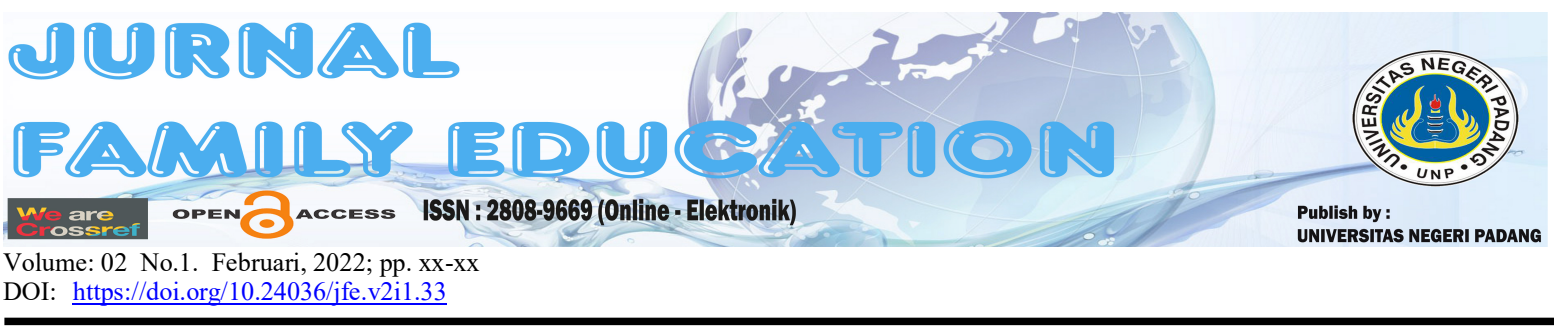

\title{
Hubungan Antara Dukungan Pemerintah Desa Dengan Partisipasi Masyarakat Dalam Pelaksanaan Pendidikan Nonformal Didesa Marunggi
}

\author{
Silvia Septriani Putri, Vevi Sunarti \\ Universitas Negeri Padang \\ * e-mail: silviaseptriani11@gmail.com
}

\begin{abstract}
This research is motivated by Community Participation in the Implementation of Education that has not run optimally in Marunggi Village, Pariaman City. There is still a lot of non-formal education that has not been implemented and many face problems. This research is a quantitative type of correlational research. Community participation in education is very low, but community participation in education is very important because whatever is produced not through community involvement in the entire process will result in a lack of sense of ownership and responsibility for them to participate in implementing and maintaining the continuity of education. The population in this study was 113 people and the sample of this study was 53 people who were enrolled in non-formal education programs with the sampling technique of cluster random sampling. The analysis of this research is Pearson product moment correlation. There is a significant relationship between government support for community participation in the implementation of non-formal education in Marunggi village, Pariaman City.
\end{abstract}

\section{Keywords: Dukungan Pemerintah Desa, Partisipasi Masyarakat, Pendidikan Nonformal}

CC) $\$$ Licensees may copy, distribute, display and perform the work and make derivative works and remixes based on it only if they give the author or
licensor the credits (attribution) in the manner specified by these. Licensees may copy, distribute, display, and perform the work and make
derivative works and remixes based on it only for non-commercial purposes.

\section{PENDAHULUAN}

Hakikat pembangunan nasional merupakan pembentukan manusia Indonesia seutuhnya serta pembanguan warga Indonesia. Dasar pembangunan nasional Indonesia merupakan Pancasila yang berupaya agar mencapai tujuan nasional ialah menghasilkan warga yang adil serta jaya. Pendidikan ialah kunci pembentukan sebuah Negara. Tingkatan mutu seseorang itu bisa lewat melewati 3 metode pendidikan, ialah pendidikan formal, informal, serta nonformal. Pendidikan nonformal mempunyai perbandingan dengan pendidikan formal. Pendidikan nonformal selaku aspek dari system pendidikan mempunyai kewajiban terhadap pendidikan yang lain ialah membagikan pelayanan terbaik terhadap masyarakat (Heningtyas et al., 2015).

Pelaksanaan pendidikan nonformal adalah salah satu upaya dalam mengembangkan kemampuan, keterampilan serta bakat yang nantinya sangat berguna dalam menyelesaikan tantangan hidup di lingkungan sosial. Selain itu, pendidikan nonformal juga sangat membantu dalam menjembatani kesenjangan yang terdapat pada pendidikan formal (Syafrudin 2016). Hal yang diperlukan dalam kegiatan pendidikan nonformal adalah partisipasi yang di berikan 
masyarakat, tidak hanya dalam bentuk materi saja, namun masyarakat juga ikut menyelenggarakan dan dan berpartispasi memberikan sumbangan tenaga serta pikiran untuk kesejahteraan masyarakat itu sendiri dalam dunia pendidikan.

Besarnya partisipasi masyarakat ditentukan dengan cara lembaga menjalin hubungan yang baik dengan masyarakat tersebut. Suryosubroto (2012) mengatakan bahwa banyak yang menjadi perhatian masyarakat untuk ikut berpartisipasi dalam sebuah program dalam bentuk perencanaan dalam membuat keputusan, pelaksanaan program serta partisipasi dalam memanfaatkan hasil dan evaluasi dalam program yang telah dilakukan.

Masyarakat seharusnya berperan penting dalam pembangunan desanya sendiri. Banyaknya masyarakat yang tidak hadir dalam kegiatan pelaksanaan pendidikan nonformal, setiap pertemuan yang diadakan masyarakat yang hadir yang aktif saja, sehingga tujuan utama dari pendidikan nonformal untuk mencerdaskan dan mensejahterakan masyarakat belum sepenuhnya terlaksana. Pendidikan nonformal seharusnya diselenggarakan oleh warga yang membutuhkan pelayanan pendidikan yang bertujuan selaku penambahan dari pendidikan formal didalam rancangan mendorong pendidikan seumur hidup yang selalu dapat dimanfaatkan (Siswanto 2012).

Desa Marunggi adalah desa yang terletak di Kota Pariaman, mengenai pendidikan nonformal telah berjalan sejak lama, pendidikan nonformal yang ada di desa Marunggi diantaranya majelis taklim, PKK, karang taruna, remaja Masjid. Berlandasan pada observasi sebelumnya yang dilakukan peneliti, didapatkan hasil bahwa dukungan pemerintah desa dalam pelaksanaan belum berjalan secara optimal. Penyebab pendidikan nonformal tidak efektif dikarenakan topoksi yang tidak berjalan dengan baik pada masing-masing pendidikan. Program tetap berjalan namun segala kebutuhan kegiatan masih berkolaborasi antara panitia dengan pemerintah desa bukan asli dari panitia pendidikan nonformal tersebut. Kelemahan yang peneliti temukan di balai Desa yang harus menjadi perhatian khusus pemerintah desa yaitu, pada administrasi desa tidak adanya buku tahunan untuk kegiatan nonformal dikarenakan berbagai hal yang tidak menjadi perhatian pemerintah desa.

Rendah partisipasi masyarakat dalam pendidikan nonformal yang di adakan di desa Marunggi. Dari 21 anggota PKK yang terdaftar hanya 5 orang yang aktif berpartisipasi, 17 anggota LPM yang terdaftar hanya 3 orang yang aktif dan berpartisipasi, dari 32 anggota TPA hanya 8 orang yang aktif dalam pelaksanaan kegiatan, sementara untuk posyandu dari 30 anggota hanya 7 orang yang aktif falam kegiatan, posyandu lansia anggota berjumlah 10 orang hanya 3 orang yang aktif berpartisipasi dan untuk karang taruna dari 35 anggota hanya 6 orang yang aktif dan berpartisipasi.

Kegiatan nonformal di bidang PKK, LPM, karang taruna belum berjalan cukup baik. Berlandaskan pada hasil observasi kedua yang dilakukan peneliti ditanggal 9 Oktober 2021, untuk partisipasi masyarakat masih dengan pencapaian target baru 70-80\%. Kegiatan nonformal dibidang kesehatan seperti posyandu balita dan lansia tetap berjalan setiap tahun dan memiliki kendala di 2020 dan 2021 karna Covid 19, namun setiap bulan dilaksanakan tetapi masih memiliki partisipasi yang rendah dimana masyarakat yang berpartisipasi dalam posyandu setiap bulannya masih orang yang sama, sedangkan masyarakat desa marunggi tergolong banyak untuk balita, remaja dan lansia.

Selain itu, masih banyak pendidikan nonformal yang belum terlaksana, dan banyak menghadapi masalah seperti: pendidikan anak usia dini yang tidak mendapatkan perhatian secara maksimal dibanding pendidikan lain, contoh pendidikan dasar ditambah terdapatnya rendah wawasan serta dikurang didukungnya kesadaran orangtua dan masyarakat mengenai pentingya pendidikan anak usia dini (PAUD), hingga menyebabkan minimnya optimal penyuluhan PAUD 
kepada semua warga, selain itu masih rendahnya peran warga terhadap keberlangsungan kegiatan Belajar (Kejar), hal lainnya masih adanya ketidaksetaraan gender dalam jenjang pendidikan, pekerjaan serta kesempatan dana yang tidak tepat sasaran seperti penyalur, total yang disalurkan, manfaat dan waktu saat dilaksanakan program atau block grant diberikan pemerintah. Masih banyak kegiatan yang di lakukan pemerintah guna menjalankan kegiatan nonformal. Oleh karena itu dibutuhkan dukungan ekstra pemerintah desa dalam menanggulangi, masalah yang pada masyarakat dengan pendidikan nonformal yang berkualitas.

Pelaksanaan pendidikan nonformal, tidak terlepas dari dukungan pemerintah desa. Peran pemerintah dilaksanakan lewati 3 sesi, ialah sesi persiapan, penerapan, serta penilaian. Dalam sesi persiapan, pemerintah memiliki peran didalam penghimpunan isu-isu strategis yang terdapat pada warga, menimbulkan kebijakan, serta memastikan rancangan-rancangan yang hendak dilakukan. Dalam sesi persiapan pemerintah berfungsi selaku regulator, sebab pemerintah memberi landasan pada masyarakat selaku indikator agar mengendalikan seluruh aktivitas layanan dari ketetapan yang telah ditentukan. Berikutnya didalam sesi penerapan, pemerintah berfungsi selaku pelaksana atas layanan itu. Tidak hanya itu, pemerintah memiliki peran selaku dinamisator yang menjalankan rancangan - rancangan yang sudah diatur serta dirancang tersebut melewati pemberian bimbingan serta arahan dengan mendalam serta efisien terhadap warga (Dinisti, 2017).

Bimbingan yang diberikan telah terlaksana disalurkan dari penyuluh ataupun aspek khusus agar memberi pelatihan. Didalam sesi ini pemerintah dapat berfungsi selaku fasilitator, yang mana membuat keadaan yang terkendali dalam menjalankan layanan agar menghubungi bermacam keperluan warga didalam memaksimalkan pembangunan. Selaku fasilitator, pemerintah berperan pada aspek pendampingan lewat pelatihan, pembelajaran, serta peningkatan keterampilan, dan pada aspek pendanaan lewat pemberian bantuan terhadap warga. Setelah itu disesi penilaian, pemerintah memiliki bagian didalam melaksanakan penilaian serta merancang laporan tentang layanan yang sudah diberi pada warga (Dinisti, 2017). Wahyudi (2016) mengatakan bahwa guna mengatasi permasalahan peningkatan kapasitas dan kemampuan aparatur desa bahwa SDM pemerintah desa dilihat dari kualitas dan kuantitas, dirasakan tidak mendukung penyelenggaraan pemerintahan desa yang sesuai visi desa. Kondisi tersebut berpengaruh terhadap rendahnya kualitas penyelenggaraan pemerintahan desa seperti kegiatan nonformal.

Berlandaskan pada kejadian yang sudah dipaparkan diatas, maka peneliti berminat meneliti mengenai "Hubungan Dukungan Pemerintah Terhadap Partisipasi Masyarakat Dalam Pelaksanaan Pendidikan Nonformal di Desa Marunggi Kota Pariaman"

\section{METODE PENELITIAN}

Penelitian ini tergolong pada penelitian kuantitatif jenis korelasional. Pendapat Arikunto (2016) penelitian korelasional memiliki tujuan dalam mempelajari ada atau tidak keterkaitan yang signifikan pada 2 variabel ataupun lebih. Peneliti dapat memakai metode korelasi, seseorang peneliti dapat memperhatikan terdapatnya keterkaitan yang beranekaragam didalam suatu variabel satu dan lainnya. Pada kali ini akan digambarkan Dukungan Pemerintah Desa (variabel X) dan Partisipasi Masyarakat dalam Pelaksanaan Pendidikan Non Formal (variabel Y) Desa Marunggi Kota Pariaman kriteria populasi penelitian ini yaitu berdasarkan umur, tempat tinggal dan responden membaca dan menulis.

Populasi penelitian merupakan seluruh warga masyarakat terlibat didalam program pendidikan nonformal di Desa Marunggi Kota Pariaman dengan jumlah 113 orang dengan cirri ciri rentang usia 17-60 tahun, memiliki ktp, berdomisili di desa Marunggi. Sampel dalam penelitian ini merupakan 53 masyarakat yang terdaftar pada pendidikan nonformal dengan teknik sampling yang dipilih merupakan Cluster Random Sampling merupakan randomisasi kelompok, bukan subjek secara individu (Azwar 2010). Nama peseta didik yang ada pada gulungan kertas yang terambil itu adalah tempat penelitian ini (Asrarudin e Dewi 2021).

(Hubungan Antara Dukungan Pemerintah...) 
Angket ditujukan kepada warga masyarakat terlibat didalam program pendidikan nonformal di Desa Marunggi Kota Pariaman. Data yang terkumpul melalui alat pengumpul data diolah dengan menggunakan teknik analisa deskriptif. Rumus yang digunakan yaitu berbasis persentase (Sugiyono 2014).

$$
P=\frac{f}{N} \times 100 \%
$$

Keterangan:

$$
\begin{aligned}
& \mathrm{P}=\text { Jumlah Persentase } \\
& \mathrm{f}=\text { Frekuensi Jawaban } \\
& \mathrm{N}=\text { Jumlah Responden }
\end{aligned}
$$

Analisis Korelasional adalah suatu metode analisis didalam statistik yang dipergunakan agar mencari ikatan antar dua variabel ataupun lebih yang memiliki sifat kuantitatif (Solfema 2021). Berikut rumus pearson product moment correlation yang dibuat oleh (Siregar 2013):

$$
r_{x y}=\frac{n \sum X Y-\left(\sum X\right)\left(\sum Y\right)}{\sqrt{\left\{n \sum X^{2}-\left(\sum X\right)^{2}\right\}\left\{n \sum Y^{2}-\left(\sum Y\right)^{2}\right\}}}
$$

Keterangan:

$\mathrm{r}_{\mathrm{xy}}=$ koefisien korelasi antara $\mathrm{x}$ dan $\mathrm{y}$

$\mathrm{n}=$ jumlah sampel diteliti

$\mathrm{x}=$ skor variabel bebas

$\mathrm{y}=$ skor variabel terika

\section{HASIL DAN PEMBAHASAN}

\section{Hasil Penelitian}

Penelitian yang dilaksanakan punya tujuan guna melihat gambaran hubungan antara dukungan pemerintah desa tentang pendidikan dengan pelaksanaan pendidikan nonformal di desa Marunggi Kota Pariaman. Agar lebih jelas, hasil penelitiannya sebagai berikut:

\section{Gambaran Data Dukungan Pemerintah Desa Marunggi Kota Pariaman}

Untuk dapat melihat gambaran distribusi skor dukungan pemerintah desa (X) dapat dilihat pada histogram berikut ini:

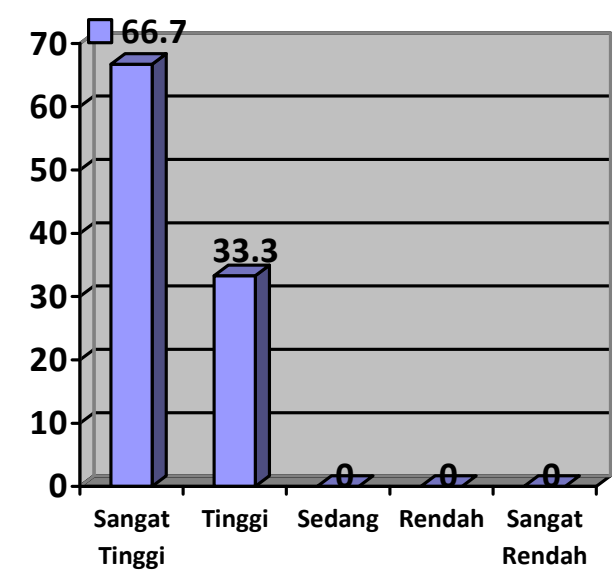

DDukungan Pemerintah

Berdasarkan gambar diatas bisa dijelaskan jika dari 54 responden untuk variabel dukungan pemerintah desa dapat dikelompokkan sebagai berikut: kategori sangat tinggi $66,7 \%$, tinggi $33,3 \%$, tidak ada responden yang menjawab didalam kategori sedang, rendah serta sangat rendah. Berlandaskan Perhitungan statistik variabel dukungan pemerintah desa berada pada klasifikasi 
skor $\geq 156$ menunjukkan bahwa dukungan pemerintah desa Marunggi dalam kategori sangat tinggi.

\section{Gambaran Data Partisipasi Masyarakat Dalam Pelaksanaan Pendidikan Nonformal}

Untuk dapat melihat gambaran kategori penilaian hasil penelitian, untuk lebih jelasnya gambaran distribusi skor Partisipasi Warga Didalam Pelaksanaan Pendidikan Nonformal (Y) bisa terlihat pada gambar berikut:

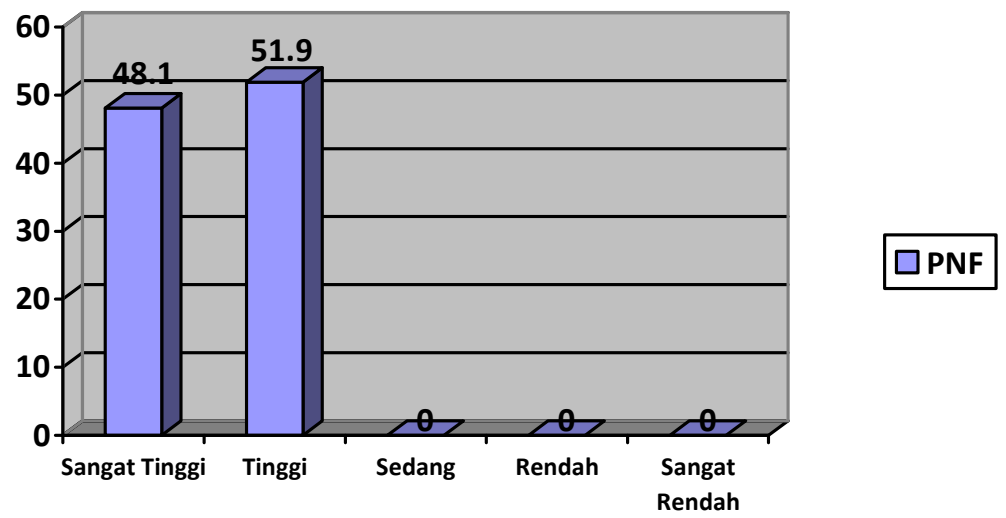

Berdasarkan gambar diatas bisa dijelaskan jika dari 54 responden untuk variabel Partisipasi Masyarakat Dalam Pelaksanaan Pendidikan Nonformal dapat dikelompokkan sebagai berikut: kategori sangat tinggi $48,1 \%$, tinggi $51,9 \%$, tidak ada responden yang menjawab didalam kategori sedang, rendah dan sangat rendah. Berdasarkan Perhitungan statistik variabel Partisipasi Masyarakat Dalam Pelaksanaan Pendidikan Nonformal berada pada klasifikasi skor 90-104 memperlihatkan jika Partisipasi Warga Didalam Pelaksanaan Pendidikan Nonformal desa Marunggi dalam kategori tinggi.

\section{Hubungan Antara Dukungan Pemerintah Dengan Partisipasi Masyarakat Dalam} Pelaksanaan Pendidikan Nonformal

Dalam penelitian dapat diketahui apakah terdapat hubungan antara Hubungan Dukungan Pemerintah Terhadap Partisipasi Masyarakat Dalam Pelaksanaan Pendidikan Nonformal Didesa Marunggi Kota Pariaman. Berikut ini adalah hasil korelasi Hubungan Dukungan Pemerintah Terhadap Partisipasi Masyarakat Dalam Pelaksanaan Pendidikan Nonformal Didesa Marunggi Kota Pariaman:

Uji Korelasi Hubungan Antara Dukungan Pemerintah dengan Partisipasi Masyarakat Dalam Pelaksanaan Pendidikan Nonformal

\begin{tabular}{|l|l|r|r|}
\hline \multicolumn{3}{|c|}{ Correlations } \\
\hline \multicolumn{2}{|c|}{} & $\begin{array}{c}\text { Dukungan } \\
\text { Pemerintah } \\
\text { Desa }\end{array}$ & $\begin{array}{r}\text { Partisipasi } \\
\text { Masyarakat }\end{array}$ \\
\hline \multirow{3}{*}{ Dukungan Pemerintah Desa } & Pearson Correlation & 1 & $.869^{*}$ \\
\cline { 2 - 4 } & Sig. (2-tailed) & & .009 \\
\cline { 2 - 4 } & N & $.869^{*}$ & 54 \\
\hline Partisipasi Masyarakat & Pearson Correlation & .009 & 1 \\
\cline { 2 - 4 } & Sig. (2-tailed) & 54 & 54 \\
\cline { 2 - 5 } & N & & \\
\hline$* *$ Correlation is significant at the 0.01 level (2-tailed).
\end{tabular}

Berdasarkan hasil analisis mengenai hasil korelasi Dukungan Pemerintah Terhadap Partisipasi Masyarakat Dalam Pelaksanaan Pendidikan Nonformal dengan koefisien korelasi $\mathrm{p}=$ $0,009$ ( $p<0,05)$ yang menandakan bahwa Ha diterima atau terdapat Hubungan Dukungan 
Pemerintah Terhadap Partisipasi Masyarakat Dalam Pelaksanaan Pendidikan Nonformal dan nilai personal correlation diperoleh bahwa 0,869, menurut Albert (2011), untuk mengetahui interpretasi tentang kekuatan keterkaitan antar dua variable maka hasil uji korelasi termasuk sangat kuat karena berkisar antara 0,80-1,000.

\section{Pembahasan}

\section{Gambaran Dukungan Pemerintah Desa Marunggi Kota Pariaman}

Dari hasil penelitian terlihat bahwasannya Dukungan Pemerintah mempunyai pengaruh terhadap partisipasi masyarakat dalam pelaksanaan pendidikan nonformal didesa Marunggi Kota Pariaman. Aparatur desa didalam menjalankan kewajiban pembangunan serta terselenggaranya layanan terhadap warga yang sudah memperhatikan keterkaitan kemitraan kerja didalam terselenggaranya pemerintahannya. Kemitraan didalam terselenggaranya pemerintahan desa memiliki arti jika didalam pelaksanaan kewajiban membangunan ataupun pemberian layanan terhadap warga, seluruh aparat pemerintahan desa, baik itu kepala desa, sekretaris desa, serta Badan Permusyawaratan Desa (BPD) wajib benar-benar mempelajari daya tampung yang menjadi wewenang ataupun kewajiban tersendiri.

Pada penelitian ini bisa ditarik simpulan yakni masyarakat di Desa Marunggi mempunyai Dukungan Pemerintah yang sangat tinggi. Pemerintahan Desa berdasarkan Undang-Undang Nomor 5 tahun 1979 disebutkan jika yang dituju dengan pemerintah desa merupakan aktifitas didalam rangkaian terselenggaranya Pemerintahan yang dilaksanakan oleh Pemerintahan yang dilaksanakan oleh Pemerintah desa dan pemerintah kelurahan. Terselenggaranya Pemerintahan Desa berlandaskan pada Undang-Undang Nomor 32 tahun 2004 pengaturannya ada pada pemikiran yang beragam, antusias, otonomi asli, demokrasi serta pemberdayaan warga (Ulumiyah, 2013). Maka penyelenggaraan pemerintahan desa adalah subsistem terselenggaranya pemerintahan, hingga desa memiliki wewenangan agar bisa mengatur serta mengurus keperluan warga.

Peranan pemerintah didalam memberi layanan terhadap warga wajib disesuaikan pada keadaan serta perkembangan mereka. Hal ini sangat dibutuhkan demi pencapaian target ataupun tujuan yang optimal. Disetiap institusi serta aparat birokrasi wajib sadar serta dapat menganalisa bagaimana keadaan warga, agar berikutnya menetapkan peranan, teknik, tindakan serta menetapkan peraturan yang menetap dengan keadaan tersebut. Keadaan sosial warga dibagi didalam tiga fase proses perkembangan, yakni Warga Terbelakang (Underdeveloped Community), Warga yang mulai membangun (developing community), dan Warga Mandiri (self-developed community) (Dinisti, 2017).

Penelitian yang dilaksanakan oleh Dinisti (2017) memperoleh hasil jika peranan Pemerintah Kabupaten Kendal didalam terselenggaranya pendidikan non formal selaku usaha peningkatan mutu sumber daya manusia di Kabupaten Kendal merupakan selaku organisator (organizer), yang memiliki arti jika Pemerintah Kabupaten Kendal adalah bagian yang membangkitkan, mendorong, memfasilitasi, serta pengelolaan ide ide dan aktifitas pembangunan di tengah warga pada aspek pendidikan non formal. Penjelanan peran tersebut terbagi menjadi 3 proses yang mana : proses persiapan pengerjaan, serta evaluasi. Akan tetapi terdapat sebagian indikator yang menjadikan hambatan, di antaranya pertama keuangan serta yang kedua merupakan sumber daya manusia didalam hal ini merupakan tenaga pengajar pendidikan non formal.

Penelitian yang dilakukan oleh Heningtyas et al. (2015) didapatkan hasil bahwa Peran warga jauh mendominasi didalam pengembangan pendidikan nonformal di Kampung Inggris, pemerintah jauh bersifat pasif dengan banyaknya dukungan serta menjadi fasilitator dengan yang dikehendaki oleh warga di Kampung Inggris. Kampung Inggris menimbulkan dampak sangat besar terkhusus kepada peningkatan ekonomi warga setempat.

\section{Gambaran Partisipasi Masyarakat Dalam Pelaksanaan Pendidikan Nonformal}

Dari simpulan pada penelitian ini sebagian besar Partisipasi Masyarakat Dalam Pelaksanaan Pendidikan Nonformal Didesa Marunggi Kota Pariaman dalam kategori tinggi. 
Pendidikan nonformal dilaksanakan kepada warga masyarakat yang membutuhkan pelayanan pendidikan yang berperan selaku pengganti, penambah, ataupun pelengkap pendidikan formal didalam rancangan mendorong pendidikan sepanjang hayat. Atau pun perannya adalah agar berkembangnya potensi-potensi peserta didik dengan penekanan terhadap kemampuan menguasai pengetahuan serta keterampilan fungsional dan pengembangan sikap serta kepribadian profesional (Sunarti 2014).

Pendapat Saleh Marzuki didalam Sunarti (2014) Peranan Pendidikan Nonformal didalam mengamati bermacam permasalah yang muncul di kalangan warga masih tidak diketahui oleh orang banyak termasuk para pendidik. Pendidikan nonformal memiliki peratan utama agar membina serta meningkatkan mutu sumber daya manusia di lingkungan warga, lembaga, serta keluarga. Satuan pendidikan nonformal merupakan kelompok belajar, kursus-kursus, pelatihan, pusat kegiatan belajar masyarakat serta majelis taklim dan satuan pendidikan sejenis. Pasal 26 Ayat 4 menerangkan jika satuan pendidikan nonformal terdiri dari lembaga kursus, lembaga pelatihan, kelompok belajar, pusat kegiatan belajar masyarakat serta majelis taklim, dan satuan pendidikan yang serupa (Presiden Republik Indonesia, 2003) dalam (Alfiyan et al., 2018).

Penelitian yang dilaksanakan Irmawita (2018) didapatkan hasil jika Program pendidikan nonformal terhadap warga lanjut usia, membutuhkan perhatian bersama, hal ini di sebabkan karena karakteristik serta potensial yang dipunya baik itu kuantitas ataupunn kualitas membutuhkan program hingga pendidikan itu dapat berjalan sepanjang hayat. Rancangan pendidikan nonformal didalam memberdayakan sekelompok warga lanjut usia bisa dilaksanakan secara efektif serta efisien hingga dapat berhasil. Penilaian keefektifan teknik pendidikan nonformal berdasarkan pada: a) tingkatan penerimaan sumber belajar (fasilitator ataupun pengelola) serta peserta rancangan (kelompok warga lanjut usia) pada rancangan pendidikan nonformal diharapkan memperoleh respon yang cukup tinggi, disebabkan tidak sedikit kelompok warga lanjut usia yang tidak memperoleh perhatian. Pendidikan itu berjalan sepanjang hayat.

Penelitian yang dilaksanakan Maani (2012) memperoleh kesimpulan jika

Partisipasi warga didalam layanan publik dimulai dari persiapan dasar layanan hingga evaluasi serta apresiasi. Warga partisipasi dapat terwujudkan didalam rupa kerjasama, upaya mencukupkan hak serta keharusan warga, dan partisipasi didalam pembuatan kebijakan dan membentuk pengawas layanan umum. Warga yang berpartisipasi merupakan bagian penting dari sistem pelayanan publik. Jadi manajemen layanan konvensional yang mengabaikan proses keterlibatan masyarakat dalam pelayanan publik tidak dapat dipertahankan lagi. Perhatian kami adalah mengembangkan bentuk partisipasi yang ideal di mana masyarakat dapat dimobilisasi sendiri untuk mencari yang diperlukan pelayanan publik.

\section{Hubungan Atara Dukungan Pemerintah Desa Dengan Partisipasi Masyarakat Dalam Pelaksanaan Pendidikan Nonformal Didesa Marunggi Kota Pariaman}

Dari hasil pengujian atara hipotesis dukungan pemerintah desa (x) dengan partisipasi masyarakat (y) di desa marunggi bahwa hipotesis yang menyatakan ada hubungan Dukungan Pemerintah Kepada Partisipasi Warga Didalam Pelaksanaan Pendidikan Nonformal di desa Marunggi Kota Pariaman dapat diterima. Terdapat dua pola yang bisa dilaksanakan didalam kerangka mengumpulkan partisipasi warga agar pembentukan ketetapan umum di era demokrasi, merupakan partisispasi tidak langsung, contohnya partisipasi dari media massa (cetak dan elektronik), serta partisipasi langsung dengan mempergunakan struktur-struktur mediasi.

Menurut Sudjana dalam Sunarti (2014) pendidikan non formal, yang diketahui oleh warga negara Indonesia dengan bermacam istilah berdasrkan perkembangannya, adalah: Pendidikan Masyarakat (Penmas), Pendidikan Sosial (Pensos), serta Pendidikan Luar Sekolah (PLS), adalah institusi ataupun lembaga pendidikan yang mempunyai rancangan pelayanan pendidikan yang luas serta kaya dan spesifik sebagai perwujudan implementasi mengenai filsafat pendidikan sepanjang hayat (life long learning). Dengan pendidikan sepanjang hayat, secara sosiologis, psikologis, ekonomis, serta filosofis baik di negara maju ataupun negara berkembang kenyataaannya sangat memerlukan PLS yang saat ini lebih dikenal dengan pendidikan nonformal (PNF), karena 
memang didalam menghadapi pembangunan bangsa serta bermacam persoalannya, tidak dipungkiri hanya bergantung pada pendidikan persekolahan ataupun pendidikan formal (PF) yang sebenarnya masih terdapat berbagai hambatan serta kritik terhadapnya.

Hasil pendidikan nonformal bisa dihargai setara dengan hasil program pendidikan formal sesudah melewati tahapan penilaian penyetaraan oleh lembaga yang ditunjukan oleh pemerintah (pusat) serta pemerintah daerah dengan berlandasakan terhadap standard nasional pendidikan (Ahmadi e Uhbiyati 2011). Kedudukan Pemerintah Desa dalam menyelenggarakan pendidikan nonformal menjadi organisator (organizer), Pemerintah Desa ialah aspek yang menyediakan, memfasilitasi, serta melakukan pengelolaan ide-ide dan aktivitas pembangunan di tengah warga di aspek pendidikan nonformal serta penerapan peran tersebut dipecah jadi tiga sesi ialah sesi persiapan, penerapan, serta penilaian. Dalam melaksanakan perannya, Pemerintah Desa membangun satuan pembelajaran yang terdapat rancangan pendidikan nonformal. Satuan pendidikan nonformal dibangun oleh Aparatur Desa itu merupakan Pusat Aktivitas Belajar Warga (PKBM), Lembaga Kursus serta Pelatihan (LKP), serta Desa Vokasi. Partispasi masyarakat yang aktif diharapkan dapat memberikan perubahan pada pendidikan nonformal yang lebih baik lagi. Besarnya partisipasi masyarakat ditentukan dengan cara lembaga menjalin hubungan yang baik dengan masyarakat tersebut. Suryosubroto (2012) mengatakan bahwa banyak yang menjadi perhatian masyarakat untuk ikut berpartisipasi dalam sebuah program dalam bentuk perencanaan dalam membuat keputusan, pelaksanaan program serta partisipasi dalam memanfaatkan hasil dan evaluasi dalam program yang telah dilakukan dalam pendidikan nonformal yang diselenggarakan.

\section{KESIMPULAN}

Kesimpulan pada penelitian Hubungan Dukungan Pemerintah Terhadap Partisipasi Masyarakat Dalam Pelaksanaan Pendidikan Nonformal di desa Marunggi Kota Pariaman, bisa dilihat dari hasil temuan dan pembahasan yaitu sebagai berikut:

1. Gambaran Dukungan Pemerintah Desa di desa Marunggi Kota Pariaman dikategorikan sangat tinggi dengan nilai persentase $66,7 \%$ pada rentang skor $\geq 156$. Penelitian ini bisa ditarik simpulan yakni masyarakat di Desa Marunggi mempunyai Dukungan Pemerintah yang sangat tinggi. Pemerintah desa dalam menjalankan kewajiban pembangunan serta pelaksanaan pelayanan terhadap warga sudah mengawasi keterkaitan kemitraan kerja didalam pelaksanaan pemerintahannya

2. Gambaran Partisipasi Masyarakat Dalam Pelaksanaan Pendidikan Nonformal dikategorikan sangat tinggi dengan nilai persentase 51,9\% pada rentang skor $90-104$. Penelitian ini bisa ditarik simpulan yakni masyarakat di Desa Marunggi mempunyai Dukungan Pemerintah yang tinggi. Maka bisa dirangkum simpulan pada penelitian ini sebagian besar Partisipasi Masyarakat Dalam Pelaksanaan Pendidikan Nonformal Didesa Marunggi Kota Pariaman dalam kategori tinggi. Pendidikan nonformal dilaksanakan terhadap warga masyarakat yang membutuhkan pelayanan pendidikan yang berperan selaku pengganti, penambah, bahkan kelengkapan pendidikan formal didalam upaya mendorong pendidikan sepanjang hayat.

3. Terdapat keterkaitan yang sangat jelas antar Dukungan Pemerintah Terhadap Antusias Warga Didalam Pelaksanaan Pendidikan Nonformal di desa Marunggi Kota Pariaman dengan demikian nilai korelasi sebesar 0,869 dengan $\mathrm{p}<\alpha 0,009$. Hal ini berarti hipotesis yang menyatakan ada hubungan Dukungan Pemerintah Terhadap Partisipasi Masyarakat Dalam Pelaksanaan Pendidikan Nonformal di desa Marunggi Kota Pariaman dapat diterima.

\section{DAFTAR PUSTAKA}

Ahmadi, Abu, e Nur Uhbiyati. 2011. Ilmu Pendidikan. Jakarta: Rineka Cipta.

Albert, Kurniawan. 2011. Serba-Serbi, Analisis Statistika dengan Cepat dan Mudah. Jakarta: Jasakom.

Alfiyan, Denih, Solfema Solfema, e Irmawita Irmawita. 2018. Hubungan antara Persepsi Peserta 
terhadap Instruktur dengan Partisipasinya dalam Mengikuti Diklatsar di KSR PMI Unit UNP». SPEKTRUM: Jurnal Pendidikan Luar Sekolah (PLS) 6(3):356.

Arikunto. 2016. «Prosedur penelitian suatu pendekatan praktik». Jakarta: Rineka Cipta.

Asrarudin, e dyah utami Dewi. 2021. Dampak Kecerdasan Emosional Dan Modal Intelektual Pada Produktivitas Belajar Online / Daring Pada Masa Pandemi Covid-19 Mahasiswa. 27(1):1-17.

Azwar, Saifuddin. 2010. Metode Penelitian. Yogyakarta: Pustaka Pelajar.

Dinisti, Afsih Lisani. 2017. Peran Pemerintah Kabupaten Kendal Dalam Menyelenggarakan Pendidikan Non Formal Sebagai Upaya Peningkatan Kualitas Sumber Daya Manusia Di Kabupaten Kendal». Departemen Politik Dan Pemerintahan Fisip Undip 53(9):1689-99.

Heningtyas, Murdiana Asih, Sjamsiar Sjamsuddin, e Minto Hadi. 2015. «Peran Pemerintah Dan Masyarakat Dalam Upaya Pengembangan Pendidikan Nonformal». Jurnal Administrasi Publik (JAP) 2(2):5.

Irmawita. 2018. Pengelolaan Program Pendidikan Nonformal untuk Kelompok Masyarakat Lanjut Usia. KOLOKIUM: Jurnal Pendidikan Luar Sekolah 6(1):1-8.

Maani, Karjuni Dt. 2012. Partisipasi Masyarakat dalam Penyelenggaraan Pelayanan Publik. Jurnal Demokrasi 8(1):17-30.

Siregar, Syofian. 2013. Metode Penelitian Kuantitatif. Jakarta: PT Fajar Interpratama Mandiri.

Siswanto. 2012. Pengantar Manajemen. Jakarta: PT.Bumi Aksara.

Solfema. 2021. Statistik Pendidikan Teori dan Praktik dalam Pendidikan Luar Sekolah Edisi Pertama. Jakarta: Kencana.

Sugiyono. 2014. Metode penelitian pendidikan pendekatan kuantitatif.pdf.

Sunarti, Vevi. 2014. Peranan Pendidikan Luar Sekolah Dalam Rangka Mitigasi Bencana. SPEKTRUM: Jurnal Pendidikan Luar Sekolah (PLS) 2(2).

Suryosubroto. 2012. Proses Belajar Mengajar di Sekolah. Jakarta: Rineka Cipta.

Syafrudin, Wahid. 2016. Komunikasi Pada Lembaga Pendidikan Nonformal: Suatu Kajian Dalam Latar Budaya Minangkabau. Jakarta.

Ulumiyah, I. 2013. Peran Pemerintah Desa Dalam Memberdayakan Masyarakat Desa (Studi Pada Desa Sumberpasir Kecamatan Pakis Kabupaten Malang). Jurnal Administrasi Publik Mahasiswa Universitas Brawijaya 1(5):890-99.

Wahyudi, Andi. 2016. Peningkatan Kapasitas Desa. Jakarta: Data Katalog PKP2A III LAN. 